\title{
Genetic evidence of multiple reproductive strategies in a microendemic and threatened cactus (Cactaceae: Discocactus Pfeiff) in Bahia, Brazil
}

\author{
Izabela Santos Dias de Jesus ${ }^{1 *}$ (1), Leila Patricio Conceiçãa ${ }^{1}$ (D), Alessandra Selbach Schnadelbach ${ }^{1}$ (D), \\ José Geraldo de Aquino Assis ${ }^{1}$ (1) and Maria Luiza Silveira de Carvalho ${ }^{1}$ (1)
}

Received: November 7, 2018

Accepted: March 28, 2019

\begin{abstract}
Discocactus zehntneri subsp. petr-halfari, an endangered taxon, is represented by a single population in an anthropized area of Bahia, Brazil, where it is suffering due to extreme extractivism. Thus, information about this cactus, such as its reproductive patterns, is urgently needed to support conservation strategies. A population genetics approach was used to determine if this subspecies has a preferential pattern of reproduction. We sampled 18 individuals, both with and without connection to parental plants, from five clumps and assessed their diversity and genetic structure using five ISSR markers. The results revealed two clumps that are genetically supported by the presence of genetically equal individuals. The other three groups presented individuals that are genetically different and similar to individuals in other clumps. These findings suggest that this subspecies has sexual and clonal reproduction and that its environmental distribution might be shaped by events of dispersion. In addition, a possible hybrid origin may explain its rates of genetic diversity. Despite all these factors, this taxon is in danger and so the development of conservation strategies to preserve its population are urgently needed, including in situ and ex situ actions such as the micropropagation in vitro, living collections and cryopreservation.
\end{abstract}

Keywords: Discocactus, ISSR, genetic variabilty, microendemism, reproductive strategies

\section{Introduction}

Discocactus is a genus of the family Cactaceae that occurs in Brazil, Bolivia and Paraguay (Machado 2004; Machado et al. 2005); this genus comprises approximately 10 to 25 species, depending on the classification system adopted (Machado 2004; Machado et al. 2005; Braun \& Esteves 2008; Santos 2013). This incongruence is basically the result of the high morphological variability within the genus, which hinders the identification of the real number of species (Buining 1980; Anderson 2001; Machado 2004).
Discocactus is one of the most critical genera of Cactaceae; its members have a high habitat specificity and live in small populations with limited geographical distribution (Machado et al. 2005). In addition, this genus suffers from extreme extractivism due to both its potential for ornamentation and the degradation of its habitat due to anthropic action (Machado et al. 2005; Santos 2013). In particular, at least 12 species of Discocactus are considered to be at-risk in some IUCN categories (2017). However, no subspecific taxa (as in, subspecies) have been included in this at-risk categorization despite being commonly recognized as such within the genus (Machado 2004; IUCN 2017).

1 Laboratório de Genética e Evolução Vegetal, Instituto de Biologia, Universidade Federal da Bahia, 40170-290, Salvador, BA, Brazil

* Corresponding author: izabelasdias@gmail.com 
Discocactus zehntneri subsp. petr-halfari represents one of these threatened taxa and is listed as critically endangered (IUCN 2017). Zachar (2008) originally described it as a single species based on differences in the stem size, flowers and number of spines when compared to D. bahiensis and D. zehntneri; in the same year, this taxon was described as a subspecies of $D$. bahiensis due to the morphological characters of its seeds (Braun \& Esteves 2008). The taxon was recently transferred to the $D$. zehntneri subspecies based on combined molecular and morphological data (Santos 2013; Santos et al. 2015). The incongruences between these classifications might suggest a hybrid origin of this taxon, between $D$. zehntneri and D. bahiensis subsp. subviridigriseus (Zachar 2008).

The subspecies is currently represented by a single population from Juazeiro in Bahia state, Brazil (Zachar 2008; Braun \& Esteves 2008; Conceição 2013; Santos et al. 2015). The individuals of this subspecies occur alongside shrub vegetation in an open, stony area of the Caatinga biome (Zachar 2008; Braun \& Esteves 2008; Conceição 2013) (Fig. 1A-C). These individuals exist in hierarchical clumps, which may contain clonal individuals (ramets) or non-clonal individuals (genets), similar to what happens in other species of Cactaceae (Harper 1977; Nobel 2002) (Fig. 1B). The plants are characterized by the presence of globular, usually solitary stems that are $5 \mathrm{~cm}$ high and 10 to $11 \mathrm{~cm}$ in diameter. Furthermore, the plants possess marginal and central spines of $25 \times 1.5 \mathrm{~mm}$, small floral buds (white flowers) approximately $4 \times 3 \mathrm{~cm}$ large, and red elongated fruits with approximately 100 small seeds at 1 x $1 \mathrm{~mm}$ (Santos et al. 2015; Zappi \& Taylor 2018). Its flowering period occurs between November and March (Santos et al. 2015).

The population of D. zehntneri subsp. petr-halfari has resisted extinction even under recent indiscriminate anthropic actions (Leal et al. 2003; Conceição 2013; Meiado et al. 2015), such as the expansion of a highway in its area of occurrence, which have destroyed approximately $50 \%$ of the plant's population (Santos et al. 2015). Despite this decrease, there is no evidence of possible steps being taken to promote the maintenance of this taxon.

According to some authors, plants found in devastated areas seem to invest in clonal reproduction due to the instability of the climate (Clark-Tapia et al. 2005b; Honnay \& Jacquemyn 2008; Mandujano et al. 2010; Ortega-Baes

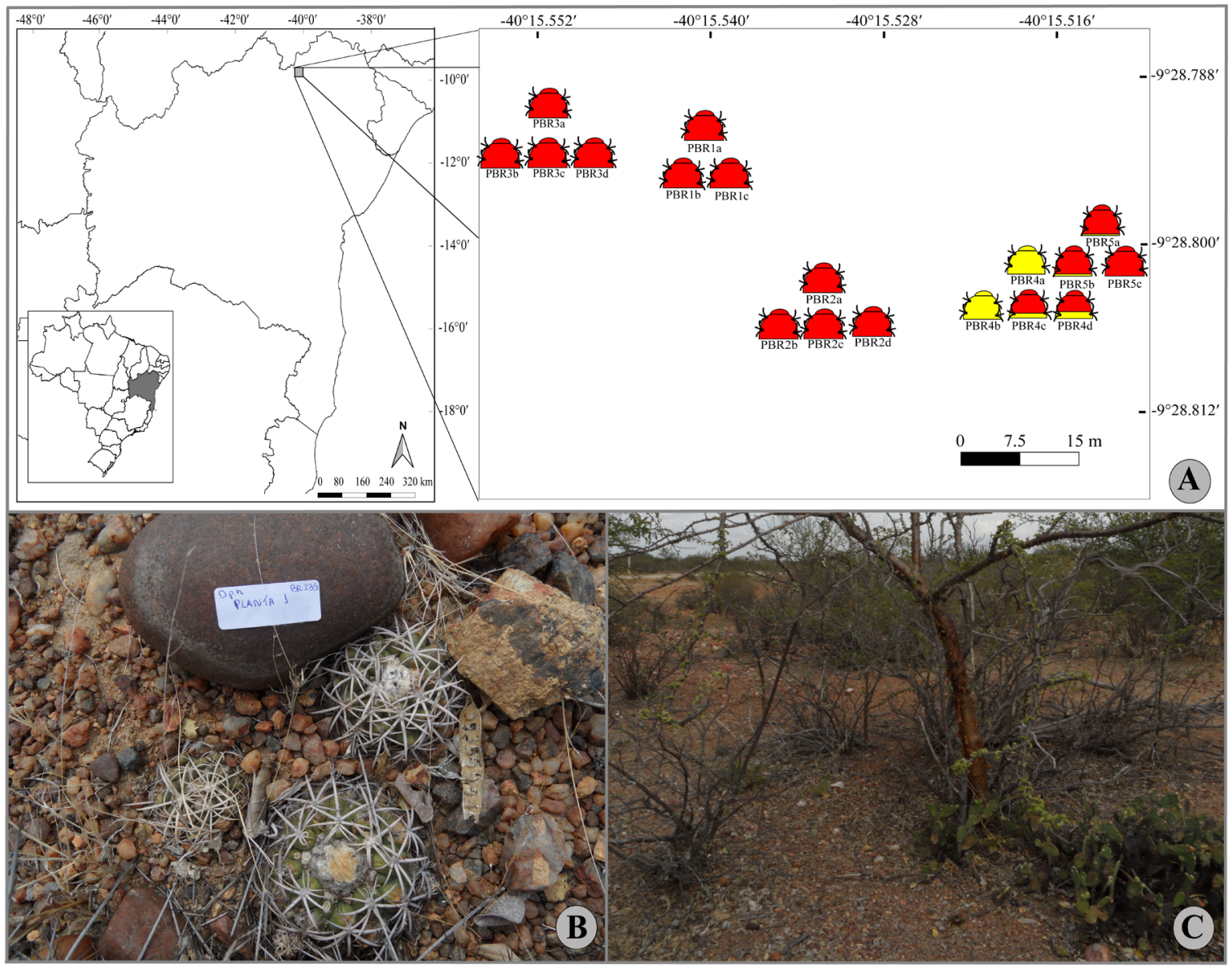

Figure 1. Distribution of D. zehntneri subsp. petr-halfari in Juazeiro, Bahia, Brazil. A. Population locality in Bahia and clumps within the population. B. Organization of clumps. C. Caatinga area were the population is found. Colors in the individuals represent the results of the Structure Analysis (see Fig. 3A). For the legend of the individuals see Table 1. 
\& Gorostiague 2013; Fukui \& Araki 2014; Blambert et al. 2016). This type of reproduction is frequently associated with population maintenance due to its high regeneration capacity and its preservation of successful genotypes (Abrahamson 1980; Caswell 1985; Cook 1985). In this sense, studies on reproductive patterns can be important both to understand population dynamics and to develop conservation strategies, especially for a population's taxa (Kearns \& Inouye 1997) as small as D. zehntneri subsp. petr-halfari.

Reproductive patterns can be assessed by evaluating the population's diversity and genetic structure via molecular markers (Eriksson \& Bremer 1993; Clark-Tapia et al. 2005a). The Inter Simple Sequence Repeats (ISSR) markers, for example, constitute an interesting and inexpensive tool for this matter because, in addition to being dominant, are abundant throughout the genome, have knowing anchorage and present a high polymorphism rate and not require a prior information for their use (Gupta et al. 1994; Zietkiewicz et al. 1994; Wolfe et al. 1998; Wolfe 2005; Grover \& Sharma 2014).

For these reasons, and to access the reproductive strategy and preferential reproduction mode of $D$. zehntneri subsp. petr-halfari, the aim of this study was to evaluate the genetic diversity and structure of this subspecies using ISSR markers. We also intend to provide information for the implementation of both ex situ and in situ conservation strategies for this subspecies.

\section{Materials and methods}

\section{Taxon sampling}

The only known population of Discocactus zehntneri subsp. petr-halfari (M.Zachar) M.R.Santos \& M.C.Machado occurs in the municipality of Juazeiro, Bahia, Brazil on the margins of highway BR 235 and at an altitude of 350-550 $\mathrm{m}\left(9^{\circ} 28^{\prime} 47.6^{\prime \prime} \mathrm{S} 40^{\circ} 15^{\prime} 33.01^{\prime \prime} \mathrm{W}\right)$ (Fig. 1A). Considering the existence of a single population we reduced our sampling. We collected 18 entire small juvenile individuals (Voucher 13514 HVASF), which were selected from five separate clumps to avoid genetically similar clumps (Tab. 1 for clumps acronyms, Fig. 1A-B). From each clump, three to four samples were collected, one of which was connected to the parental through the roots (branches) (Tab. 1).

Table 1. Information on the five clumps of D. zehntneri subsp. petr-halfari collected in Juazeiro, Bahia, Brazil and analyzed in the present study. For the location of the clumps see Figure 1A.

\begin{tabular}{|c|c|c|c|}
\hline Clumps & Sample size & Latitude & Longitude \\
\hline PBR1 & 3 & $9^{\circ} 28^{\prime} 47.6 ” S$ & $40^{\circ} 15^{\prime} 32.62^{\prime \prime} \mathrm{W}$ \\
\hline PBR2 & 4 & $9^{\circ} 28^{\prime} 47.54^{\prime \prime} S$ & $40^{\circ} 15^{\prime} 33.23^{\prime \prime} \mathrm{W}$ \\
\hline PBR3 & 4 & $9^{\circ} 28^{\prime} 48.25^{\prime \prime} S$ & $40^{\circ} 15^{\prime} 31.86^{\prime \prime} \mathrm{W}$ \\
\hline PBR4 & 4 & $9^{\circ} 28^{\prime} 48.09^{\prime \prime} S$ & $40^{\circ} 15^{\prime} 30.92^{\prime \prime} \mathrm{W}$ \\
\hline PBR5 & 3 & $9^{\circ} 28^{\prime} 48.03^{\prime \prime} S$ & $40^{\circ} 15^{\prime} 30.76^{\prime \prime} \mathrm{W}$ \\
\hline
\end{tabular}

\section{DNA extraction and amplification}

All individuals were previously dehydrated in a heater at $60^{\circ} \mathrm{C}$ to facilitate maceration, and DNA extraction was performed on the epidermis via the $2 \%$ CTAB (Cetyltrimethyl-ammonium bromide) protocol (Doyle \& Doyle 1987), which was modified for microtubes as proposed by Conceição (2013). Protocols using root fragments, which would avoid the death of the individuals, were not used due to difficulties with bacteria in biological soil disinfestation and the use of specific, high-cost kits. The extracted DNA was quantified in an L-Quant spectrophotometer, analyzed in agarose gel (1\%) with $1 \mathrm{x}$ TAE buffer, stained with ethidium bromide and visualized under ultraviolet light.

Amplifications were performed through the Polymerase Chain Reaction (PCR) for five ISSR markers, which are recognized as polymorphic for this subspecies (Conceição 2013) (Tab. 2). For the PCR, we used the TopTaq Master Mix Kit (QIAGEN), following the manufacturer's protocol and adding $6 \mu \mathrm{M}$ of primer and approximately $50 \mathrm{ng}$ of DNA template. The amplification reactions were performed in the Veriti Thermal Cycler (Applied Biosystems), beginning with an initial denaturing at $94^{\circ} \mathrm{C}$ for $1.5 \mathrm{~min}$, followed by 35 cycles of denaturing at $94^{\circ} \mathrm{C}$ for $40 \mathrm{~s}$, annealing at $45^{\circ} \mathrm{C}$ for $45 \mathrm{~s}$ with an extension at $72{ }^{\circ} \mathrm{C}$ for $1.5 \mathrm{~min}$, then one cycle of denaturing at $94{ }^{\circ} \mathrm{C}$ for $45 \mathrm{~s}$, annealing at $44{ }^{\circ} \mathrm{C}$ for $45 \mathrm{~s}$, and then a final extension at $72{ }^{\circ} \mathrm{C}$ for $7 \mathrm{~min}$. The PCR products were analyzed in $1.4 \%$ agarose gel with $1 \mathrm{x}$ TAE buffer, stained with ethidium bromide and visualized under ultraviolet light. The band profiles were read manually and encoded in a presence (1) or absence (0) data matrix.

\section{Data analysis}

The genetic diversity of the individuals was calculated using GenAlEx 6.5 software (Peakall \& Smouse 2012), estimating the number of loci $(\mathrm{N})$, the mean expected heterozygosity $(\mathrm{He})$ and the percentage of polymorphic loci $(\mathrm{P})$. The genetic identities between and within the clumps were identified using Nei's unbiased genetic identity measure (Nei 1978) also through software GenALEx 6.5. To infer the genetic relationship between the individuals, a cluster analysis was performed using the Jaccard similarity coefficient and a pairwise analysis with Ward's method (Jaccard 1908; Ward 1963); both analyses were run with the PAST 3.07 (PAleontological STatistics) program (Hammer et al. 2001).

To calculate the number of genetic groups (K), two Bayesian Inference was performed, using Structure 2.3.3 (Falush et al. 2003) and Geneland v. 4.0.8 (Guillot et al. 2005). In the first analysis the admixture model and the correlated allele frequencies were used due to the dominant nature of the marker. We used 10 independent runs with 750,000 Markov Chain Monte Carlo (MCMC) repetitions and a 250,000 burn-in for each value of $\mathrm{K}$, which ranged 
from 1 to 4 . The results were then analyzed using Structure Harvester 0.6.94 (Earl \& Holdt 2012), where the graphs of the estimated parameters were recovered and the most probable K was confirmed (Pritchard et al. 2000; Evanno et al. 2005). For the analysis on the Geneland software, in turn, a spatial grouping method was implemented in the R environment 3.4.1 (R Development Core Team 2017). We used 1,000,000 Markov Chain Monte Carlo (MCMC) repetitions, saving every 5,000 interactions and the burnin period of 200. Was realized 10 independent runs were performed, testing from one to five groups $(\mathrm{K})$ in each run. The best parameter of analyze was chosen based on the highest posterior probabilities for clusters

\section{Results}

\section{Population genetic diversity}

The results revealed the presence of 39 loci within the population (see Tab. 1 for clumps acronyms), 30 of which were polymorphic (79.93\%), and a mean value of approximately 7.8 loci per primer (results not shown). The mean expected heterozygosity found for the population was 0.080 . The analysis of Nei's unbiased genetic identity measure revealed moderate to high values of genetic similarity for the studied population, with an average of 0.809 due to PBR2 and PBR3, which were the most related clumps (0.951) (Tab. 2). Within the PBR1 and PBR 3 clumps, the values of genetic identity were 1.000 for all individuals. Already within PBR2, PBR4 and PBR5 clumps, the values of genetic identity were $0.871,0.696$ and 0.812 , respectively (Tab. 2), and we found individuals with high (0.846-1.000) and moderate to low rates of genetic similarity (0.7950.538) (Tab. 2).

Finally, the cluster analysis revealed that the previously selected clumps did not necessarily correspond to the genetic groups for both the clonal (PBR1 and PBR3) and non-clonal (PBR2, PBR4 and PBR5) clusters; there were differences in genetic relation presented by both Jaccard's similarity coefficient and Ward's method (Fig. 2A-B).

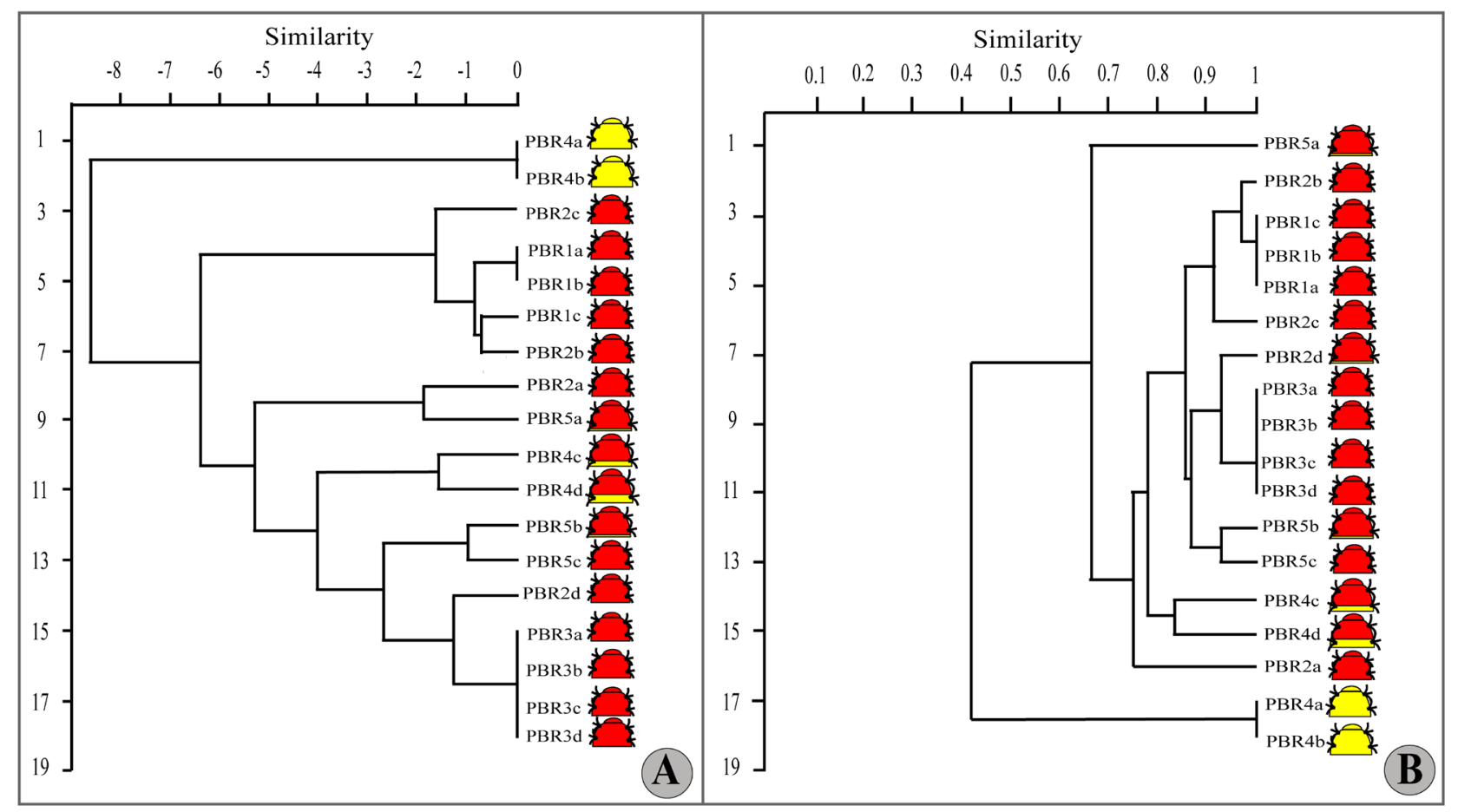

Figure 2. Sumary of the populational genetic diversity. A. Jaccard's Coefficient of Similarity. B. Ward's Method. Colors in the individuals represent the results of the Bayesian analysis through Structure (see Fig. 3A). For the legend of the individuals see Table 1.

Table 2. Nei Unbiased Genetic Identity (Nei 1978) estimated based on the ISSR patterns among and within D. zehntneri subsp. petr-halfari and clumps. For the legend of the clumps see Table 1 and Figure $1 \mathrm{~A}$.

\begin{tabular}{|c|c|c|c|c|c|c|c|c|c|c|c|c|c|c|c|c|c|c|c|}
\hline & PBR1 & PBR2 & PBR3 & PBR4 & PBR5 & & PBR2a & PBR2b & PBR2c & PBR2d & & PBR4a & PBR4b & PBR4C & PBR4d & & PBR5a & PBR5b & PBR5c \\
\hline PBR1 & ----- & ------ & ---- & ----- & ----- & PBR2a & ---- & ----- & ----- & ----- & PBR4a & ---- & ----- & ----- & ----- & PBR5a & ----- & ----- & ---- \\
\hline PBR2 & 0.924 & ----- & ----- & ----- & ----- & PBR2b & 0.795 & ----- & ----- & ----- & PBR4b & 1.000 & ----- & ----- & ----- & PBR5b & 0.846 & ----- & ----- \\
\hline PBR3 & 0.872 & 0.951 & ----- & ----- & ----- & PBR2c & 0.846 & 0.949 & ----- & ----- & PBR4C & 0.538 & 0.538 & ----- & ----- & PBR5c & 0.795 & 0.795 & ----- \\
\hline PBR4 & 0.686 & 0.678 & 0.698 & ----- & ----- & PBR2d & 0.795 & 0.949 & 0.897 & ----- & PBR4d & 0.615 & 0.615 & 0.872 & ----- & & & & \\
\hline PBR5 & 0.812 & 0.921 & 0.871 & 0.679 & ----- & & & & & & & & & & & & & & \\
\hline
\end{tabular}




\section{Populational genetic structure}

The same numbers of genetic cluster within the population $(\mathrm{K}=2)$ was chosen in both Bayesian inferences (Figs. 1A, 3A-C) (Fig. S1 in supplementary material). Bayesian analysis through Structure indicated that the individuals of the clumps PBR1, PBR2, PBR3 and PBR5 presents an only genetic pool (Figs. 1A, 3A). On the other hand, the clump PBR4 presented two individuals are from a different genetic pool (PBR4a and PBR4b) and two others
(PBR4c and PBR4d), a mixture between the two genetic pools found (Figs. 1A, 3A. In addition, it is possible to observe that, although individuals of PBR5 are composed exclusively of a single genetic pool, PBR5a and PBR5b have a slight mixture with the genetic pool of PBR4.The Bayesian analysis used the Geneland software confirm the previous analysis from the Structure showing that the individuals from the PBR1, PBR2, PBR3 and PBR5 clusters belong to the same genetic pool (Fig. 3B), while the individuals from PBR4 compose a different genetic pool (Fig. 3C).

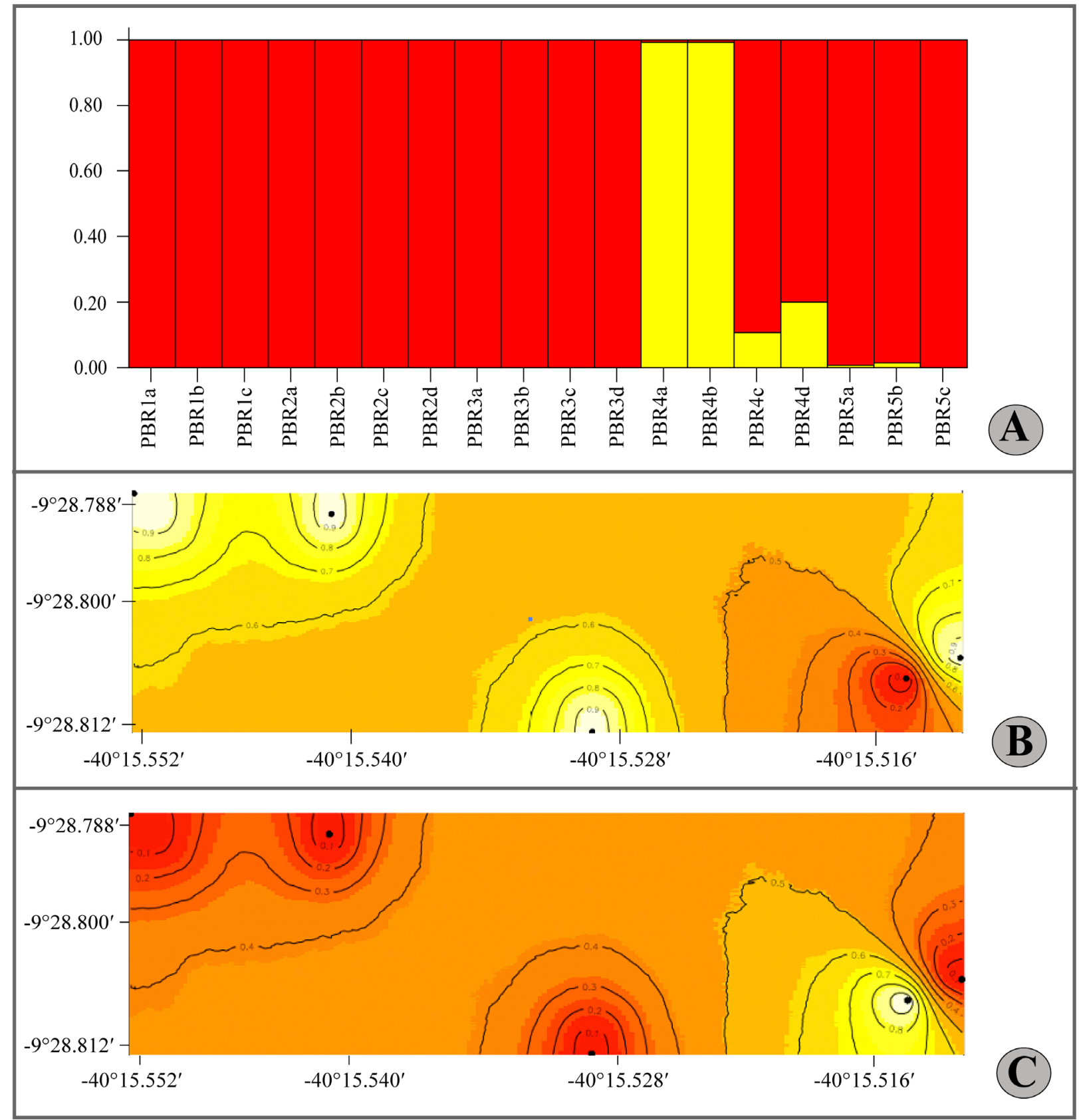

Figure 3. Population genetic structure based on Bayesian Inference. A. Results of the clustering analysis by $S t r u c t u r e$ for $K=2$. B. Spatial distribution of cluster 1 defined by Geneland for $\mathrm{K}=2$. C. Spatial distribution of cluster 2 defined by Geneland for $\mathrm{K}=2$. Yellow color in B and C indicate high likelihood rates for individuals from the same cluster. The red color indicates a smaller probability of the individuals belonging to that cluster. 


\section{Discussion}

\section{Discocactus zehntneri subsp. petr-halfari genetic characterization}

The results of this study revealed that three of the analyzed D. zehntneri subsp. petr-halfari clumps (clumps PBR2, PBR4 and PBR5) presented low to moderate rates of genetic similarity with individuals of the same clumps and high rates with individuals of different clusters, except to PBR4. The clumps also exhibited relatively moderate to high rates in relation to the percentage of polymorphic loci when compared to values commonly found in other cacti species (Figueredo et al. 2010).

The cluster analyses showed that individuals from different clusters are genetically similar. These results suggest that the clumps selected for this study are not genetically supported and, surprisingly, that half of the individuals analyzed are genetically different. Furthermore, the analyses of genetic similarity reveal that two of the study clumps consisted exclusively of clonal individuals. The Bayesian analysis showed that the population is genetically homogeneous, with a group presented a different genetic pool composition, indicating that this subspecies can carry out both sexual and clonal reproduction.

Similar reproductive patterns were found by Ribeiro et al. (2015) when they studied six species of cacti (Arrojadoa rhodantha, Pilosocereus gounellei subsp. gounellei, Melocactus zehntneri, Cereus jamacaru subsp. jamacaru, Tacinga inamoena and Tacinga palmadora); their study illustrated that these six species exhibit dynamic between sexual and clonal reproduction. Interestingly, three of the studied species (A. rhodantha, P. gounellei subsp. gounellei and M. zehntneri) are phylogenetically related to Discocactus (HernándezHernández et al. 2011), which provides an explanation for the similar pattern found by our results.

Additionally, this dynamic between both types of reproduction (sexual and asexual) might be important for the dominance of these species in Caatinga environments since the rapid formation of new individuals by clonal reproduction can facilitate their permanence in stressful environments (Mandujano et al. 1998; Pimienta-Barrios \& Castillo 2002); sexual reproduction through cross-breeding, for example, can maintain genetic diversity and enable multiple biological interactions (Abrahamson 1980; Stearns 1987). A similar situation was discovered by Lenzi \& Orth (2012) for the genus Opuntia, in which the high frequency of both types of reproduction also seems important for maintaining the population (Rebman \& Pinkava 2001; Lenzi \& Orth 2012).

In relation to rates of clonal reproduction, despite the lower values found in the present study, our results might indicate that $D$. zentneri subsp. petr-halfari invests in this type of reproduction as a response to environmental conditions, with long periods of high temperatures and sporadic rainfall (Alés et al. 1993; Polis 1991) and anthropic impacts in their area (Ayyad 2003; McNeely 2003). These events may affect seedling establishment and the reduction of both partners and pollinators, which are essential for successful sexual reproduction (Honnay \& Jacquemyn 2008; Mandujano et al. 2010; Ortega-Baes \& Gorostiague 2013; Fukui \& Araki 2014; Blambert et al. 2016). Similary, studies with Cactaceae species like Stenocereus eruca and Tacinga palmadora also demonstrate a high investment in clonal reproduction probably associated with habitat degradation (Clark-Tapia et al. 2005b; Lenzi \& Orth 2012; Meiado 2012).

The clonal reproduction could also represent an alternative of growing in polyploid species, which often have sterility problems (Eckert 2002). Opuntia monacantha, recently indicated as a plolyploid $(2 \mathrm{n}=44)$ by Realini et al. (2014). However, according to other studies, neither $O$. monacantha or $S$. eruca constitute polyploid species $(2 \mathrm{n}=$ 22 in both) (Molina-Freaner \& Clark-Tapia 2005; Peñas et al. 2017), or even, D. zenthneri $(2 \mathrm{n}=22)$ (Assis et al. 2014), suggesting the same situation for D. zentneri subsp. petrhalfari. Considering this information, it is probable that the clonal reproduction in D. zentneri subsp. petr-halfari represents a strategy for the population maintenance in a changeable environment.

In addition, D. zehntneri subsp. petr-halfari has a low self-pollination potential ( $4.2 \%)$, which associated with the decrease of pollinators (common in fragmented environments) could lead to an increase in clonal reproduction rates (Rathcke \& Jules 1993; Wilcock \& Neiland 2002; Martínez-Peralta \& Mandujano 2011).

Furthermore, our results revealed that the genetic diversity of this subspecies could be explained by both sexual reproduction and hybridization, since $D$. zenhtneri subsp. petr-halfari presents higher diversity rates when compared to other taxa of the genus (Zachar 2008; Conceição 2013). As demonstrated by other studies, species with a hybrid origin tend to have higher levels of genetic diversity due to the high rates of gene flow through new gene recombinations (Lewontin \& Birch 1966; Suehs et al. 2004; Qian et al. 2006; Abbott et al. 2013; Chunco 2014). This process can promote the acquisition alleles which might facilitate adaptive evolution (Lewontin \& Birch 1966; Abbott et al. 2013; Chunco 2014).

\section{Reproductive patterns in $\mathbf{D}$. zehntneri subsp. petr- halfari}

The formation of ramets in D. zehntneri subsp. petrhalfari appears to occur through rooting, as is the case for other cacti species, such as Cylindropuntia imbricata, Opuntia macrocentra, O. rastrera and Cylindropuntia leptocaulis (Allen et al. 1991; Mandujano et al. 1998; 2007; Flores-Torres \& Montaña 2012). However, in extreme climatic conditions and high solar incidences, such as in the Caatinga biome, vegetative propagation by rooting can be highly affected, 
as observed for the Cylindropuntia leptocaulis cactus (Flores-Torres \& Montaña 2012). Though, in more stable environments with periodic rainfall, cacti species with ramet formation present higher rates of asexual reproduction (Flores-Torres \& Montaña 2012), which may reveal changes in asexual reproduction rates in different environmental conditions through the year.

Another interesting clonal reproduction strategy reported for Cactaceae involves the formation of clonal propagules, which can be easily dispersed, root and sprout through the stem tissue that surrounds the fruits (Scheinvar 1985; Stevens 2001 onwards, Lenzi et al. 2012; Lenzi \& Orth 2012). This type of clonal reproduction could also explain, in the current study, the presence of genetically related individuals of both clonal and sexual origin in the same clumps. According to this idea, fruits that originate from clonal propagules can create individuals of sexual origin with their seeds; though, this type of tissue in fruits has never been reported in D. zehntneri subsp. petr-halfari until the present.

Additionally, the dispersion of cacti seeds has been documented for Discocactus and Melocactus in favor of ants and lizards, respectively (Fonseca et al. 2012; Oliveira 2013; Conceição 2013; Gomes et al. 2014). According to some studies, ants can disperse seeds as far as 15.7 meters (Oliveira 2013; Conceição 2013), while lizards usually only carry the fruits at short distance, leaving them just a few meters away from where they were collected (Fonseca et al. 2012; Gomes et al. 2014). However, this type of dispersal was excludes by Oliveira (2013) for D. zehntneri subsp. boomianus due to the disposition of the fruits inside the spines, which would make dispersion by vertebrates impossible, according to this author.

The fruits of D. zehntneri subsp. petr-halfari are situated in the apical portion of the cephalium (above the spines) and are produced one at the time, allowing for dispersion by lizards (Zachar 2008; Braun \& Esteves 2008; Santos et al. 2015). This type of dispersion could also explain the presence of individuals in different clumps that are genetically related but dissimilar (due to their sexual origin).

\section{Conservation of $\boldsymbol{D}$. zehntneri subsp. petr-halfari}

Despite the fact that D. zehntneri subsp. petr-halfari possesses moderate levels of genetic diversity and a large number of exclusive alleles compared to other species of Discocactus according Conceição (2013), this subspecies it still faces serious risks of extinction, which is mainly due to the destruction of its habitat by anthropic actions (Santos et al. 2015). In this way, actions are essential to preserve and maintain D. zehntneri subsp. petr-halfari genotypes.

As this taxon has been deemed critically endangered (Santos et al. 2015; IUCN 2017), the implementation of specific conservation strategies is needed. While wider strategies occur for the family under the initiative "Plano de Ação Nacional para Conservação das Cactáceas" (PAN Cactáceas) (Assis et al. 2011), this subspecies has not been completely covered by this initiative despite the drastic loss of individuals, the increase in anthropic activity in its area of occurrence and the extraction of individuals in sexual maturity (Santos et al. 2015).

Considering the drastic habitat loss faced by this subspecies, one of the main conservation strategies should include in situ conservation (Santos et al. 2015). This action could also protect several populations of $D$. bahiensis, which, despite its high number of individuals and high genetic and morphological diversity, also faces erosion due to anthropic actions (Machado 2004). Previous studies have already suggested creating a conservation unit in this particular area of Caatinga (Machado 2004; Conceição 2013), and it should be considered a priority by government authorities.

Furthermore, it is important to create complementary initiatives, such as ex situ conservation (MMA 1992), considering their viability and simplicity to maintain a species (Cohen et al. 1991). Some studies have already been carried out for endangered species of cacti examining conservation initiatives such as micropropagation in vitro (Marchi 2016; Palacios et al. 2016; Civatti et al. 2017a; b; Torres-Silva et al. 2018), living collections (Hultine et al. 2016; Cavalcante et al. 2017) and seed storage (Civatti et al. 2015; Nascimento \& Meiado 2016; Santos et al. 2018); these works are crucial to facilitate future studies and to protect the species from extinction.

\section{Acknowledgements}

The authors are thankful to FAPESP and CAPES for the scholarship grants of IC and PNPD of ISDJ and MLSC respectively; to FAPESB (Project PRONEM TO 0020/2011), PPBIO Semi-Árido project (CNPq) and the Plano de Ação Nacional de Conservação de Cactáceas (PAN Cactáceas) of the Instituto Chico Mendes de Conservação da Biodiversidade (ICMBio), for the financial support.

\section{References}

Abbott R, Albach D, Ansell S, et al. 2013. Hybridization and speciation. Journal of Evolutionary Biology 26: 229-246.

Abrahamson WG. 1980. Demography and vegetative reproduction. In: Solbrig OT. (eds.) Demography and evolution in plant populations. Berkeley, University of California Press. p. 89-106.

Alés RF, Laffarga JM, Ortega F. 1993. Strategies in Mediterranean grassland annuals in relation to stress and disturbance. Journal of Vegetation Science 4: 313-322.

Allen LJS, Allen EJ, Kunst CRG, Sosebee RE. 1991. A diffusion model for dispersal of Opuntia imbricata (Cholla) on rangeland. The Journal of Ecology 79: 1123-1135.

Anderson EF. 2001. The cactus family. Portland, Timber Press.

Assis JGA, Resende SV, Bellintani MC, et al. 2011. Conservação ex situ. In: Silva SR, Zappi D, Taylor N, Machado M. (org.) Plano de Ação Nacional Para Conservação das Cactáceas - Série espécies ameaçadas. Brasília, Instituto Chico Mendes de Conservação da Biodiversidade. p. 42-52. 


\section{Izabela Santos Dias de Jesus, Leila Patricio Conceição, Alessandra Selbach Schnadelbach, José Geraldo de Aquino Assis and Maria Luiza Silveira de Carvalho}

Assis JGA, Senra JFV, Botelho RB, Santos AB, Schnadelbach AS. 2014. Variação cromossômica em Cactáceas. Ciência e Natura 36: 267-278.

Ayyad MA. 2003. Case studies in the conservation of biodiversity: degradation and threats. Journal of Arid Environments 54: 165-182.

Blambert L, Mallet B, Humeau L, Pailler T. 2016. Reproductive patterns, genetic diversity and inbreeding depression in two closely related Jumellea species with contrasting patterns of commonness and distribution. Annals of Botany 118: 93-103.

Braun PJ, Esteves E. 2008. Zur taxonomie von Discocactus bahiensis subsp. petr-halfari. Kakteen und Andere Sukkulenten 59: 183-184.

Buining AFN. 1980. The genus Discocactus Pfeiffer: a revision of known, and description of new, species. Nederlandse-Belgische Vereniging, Succulenta.

Caswell H. 1985. Evolutionary demography of clonal organisms. In: Jackson JBC, Buss LW, Cook RE, Ashmun JW. (eds.) Population biology and evolution of clonal organisms. New Haven, Yale University Press. p. 187-224.

Cavalcante ADMB, Gomes VGN, Vasconcelos GCLD, Meiado MV. 2017. Ex situ conservation of Cactaceae in the Brazilian semiarid: Cactarium Guimarães Duque. Cactus and Succulent Journal 89: 24-27.

Chunco AJ. 2014. Hybridization in a warmer world. Ecology and Evolution 4: 2019-2031.

Civatti LM, Marchi MNG, Bellintani MC. 2015. Cryopreservation of cacti seeds of three ornamental species endemic to the state of Bahia, Brazil. Seed Science and Technology 43: 1-7.

Civatti LM, Marchi MNG, Bellintani MC. 2017a Micropropagation of two species of Micranthocereus (Cactaceae) with ornamental potential native to Bahia, Brazil. African Journal of Biotechnology 16: 749-762.

Civatti LM, Marchi MNG, Schnadelbach AS, Bellintani MC. 2017b. In vitro multiplication and genetic stability of two species of Micranthocereus Backeb. (Cactaceae) endemic to Bahia, Brazil. Plant Cell, Tissue and Organ Culture 131: 537-545.

Clark-Tapia R, Alfonso-Corrado C, Eguiarte LE, Molina-Freaner F. 2005a. Clonal diversity and distribution in Stenocereus eruca (Cactaceae), a narrow endemic cactus of the Sonoran Desert. American Journal of Botany 92: 272-278.

Clark-Tapia R, Mandujano MC, Valverde T, Mendoza A, Molina-Freaner F. 2005b. How important is clonal recruitment for population maintenance in rare plant species? The case of the narrow endemic cactus, Stenocereus eruca, in Baja California, México. Biological Conservation 124: 123-132

Cohen JI, Williams JT, Plucknett DL, Shands H. 1991. Ex situ conservation of plant genetic resources: global development and environmental concerns. Science 253: 866-872.

Conceição LP. 2013. Estrutura genética de populações de Discocactus Pfeiffer (Cactaceae) e implicações para sua taxonomia e conservação. MSc Thesis, Universidade Federal da Bahia, Salvador.

Cook RE. 1985 Growth and development in clonal plant populations. In: Jackson JBC, Buss LW, Cook RE. (eds.) Population biology and evolution of clonal organisms. New Haven, Yale University Press. p. 259-296.

Doyle JJ, Doyle JL. 1987. A rapid DNA isolation method for small quantities of fresh tissues. Phytochemical Buletin 19: 11-15.

Earl DA, Holdt BM. 2012. Structure Harvester: a website and program for visualizing structure output and implementing the Evanno method. Conservation Genetics Resources 4: 359-361.

Eckert CG. 2002. The loss of sex in clonal plants. In: Stuefer JF, Erschbamer B, Huber H, Suzuki JI. (eds.) Ecology and evolutionary biology of clonal plants. Dordrecht, Springer. p. 279-298.

Eriksson O, Bremer B. 1993. Genet dynamics of the clonal plant Rubus saxatilis. Journal of Ecology 81: 533-542.

Evanno G, Regnaut S, Goudet J. 2005. Detecting the number of clusters of individuals using the software structure: a simulation study. Molecular Ecology 14: 2611-2620.

Falush D, Stephens M, Pritchard JK. 2003. Inference of population structure using multilocus genotype data: linked loci and correlated allele frequencies. Genetics 164: 1567-1587.

Figueredo CJ, Nassar JM, García-Rivasand AE, González-Carcacía JA. 2010. Population genetic diversity and structure of Pilosocereus tillianus
(Cactaceae, Cereeae), a columnar cactus endemic to the Venezuelan Andes. Journal of Arid Environments 74: 1392-1398

Flores-Torres A, Montaña C. 2012. Recruiting mechanisms of Cylindropuntia leptocaulis (Cactaceae) in the southern Chihuahuan desert. Journal of Arid Environments 84: 63-70.

Fonseca RBS, Funch LS, Borba EL. 2012. Dispersion of Melocactus glaucescens and $M$. paucispinus (Cactaceae) in the municipality of Morro do Chapéu, Chapada Diamantina - BA. Acta Botanica Brasilica 26: 481-492.

Fukui S, Araki KS. 2014. Spatial niche facilitates clonal reproduction in seed plants under temporal disturbance. PLOS ONE 9: e116111. doi: 10.1371/journal.pone.011611

Gomes VGN, Quirino ZGM, Machado IC. 2014. Pollination and seed dispersal of Melocactus ernestii Vaupel subsp. ernestii (Cactaceae) by lizards: an example of double mutualism. Plant Biology 16: 315-322. Grover A, Sharma PC. 2014. Development and use of molecular markers: past and present. Critical Reviews in Biotechnology 36: 290-302.

Guillot G, Mortier F, Estoup A. 2005. Geneland: A program for landscape genetics. Molecular Ecology Notes 5: 712-715.

Gupta M, Chyi Y, Romero-Severson J, Owen YJ. 1994. Amplification of DNA markers from evolutionary diverse genomes using single Primers of simple sequence repeats. Theoretical and Applied Genetics 89: 998-1006.

Hammer O, Harper DA, Ryan PD. 2001. PAST: Paleontological Statistics software package for education and data analysis. Palaeontologia Electronica 4: 1-9.

Harper JL. 1977. Population biology of plants. London, Academic Press. Hernández-Hernández T, Hernández HM, De-Nova JA, Puente R, Eguiarte LE, Magallón S. 2011. Phylogenetic relationships and evolution of growth form in Cactaceae (Caryophyllales, Eudicotyledoneae). American Journal of Botany 98: 44-61.

Honnay O, Jacquemyn H. 2008. A meta-analysis of the relation between mating system, growth form and genotypic diversity in clonal plant species. Evolutionary Ecology 22: 299-312.

Hultine KR, Majure LC, Nixon VS, et al. 2016. The role of botanical gardens in the conservation of Cactaceae. BioScience 66: 1057-1065.

IUCN. 2017. The IUCN Red List of Threatened Species. Version 2017.3. http://www.iucnredlist.org. 2 May 2018.

Jaccard P. 1908. Nouvelles researches sur la distribution florale. Bulletin de la Société vaudoise des sciences naturelles 44: 223-270.

Kearns CA, Inouye DW. 1997. Pollinators, flowering plants, and conservation biology. Bioscience 47: 297-307.

Leal IR, Tabarelli M, Da Silva JMC. 2003. Ecologia e conservação da Caatinga. Recife, Editora Universitária UFPE.

Lenzi M, Graipel ME, Matos JZ, Fraga AM, Orth AI. 2012. Dispersão zoocórica e hidrocórica marítima de Opuntia monacantha (Willd.) Haw. (Cactaceae). Biotemas 25:47-53.

Lenzi M, Orth AI. 2012. Mixed reproduction systems in Opuntia monacantha (Cactaceae) in Southern Brazil. Brazilian Journal of Botany 35: 49-58.

Lewontin RC, Birch LC. 1966. Hybridization as a source of variation for adaptation to new environments. Evolution 20: 315-336.

Machado MC. 2004. O gênero Discocactus Pfeiff. (Cactaceae) no estado da Bahia, Brasil: variabilidade morfológica, variabilidade genética, taxonomia e conservação. MSc Thesis, Universidade Estadual de Feira de Santana, Feira de Santana.

Machado MC, Zappi DC, Taylor NP, Borba EL. 2005. Taxonomy and conservation of the Discocactus Pfeiff. (Cactaceae) species occurring in the state of Bahia, Brazil. Bradleya 23: 41-56.

MMA - Ministério do Meio Ambiente. 1992. Convenção sobre diversidade biológica. http://www.mma.gov.br. 24 Apr. 2018.

Mandujano MDC, Montaña C, Méndez I, Globulov J. 1998. The relative contributions of sexual reproduction and sexual propagation in Opuntia rastrera from two habitats in the Chihuahuan Desert. Journal of Ecology 86: 911-921

Mandujano MC, Golubov J, Huenneke L. 2007. Effect of the reproductive modes and environmental heterogeneity in the population dynamics of a geographically widespread clonal desert cactus. Population Ecology 49:141-153. 


\section{Genetic evidence of multiple reproductive strategies in a microendemic and threatened cactus (Cactaceae: Discocactus Pfeiff) in Bahia, Brazil}

Mandujano MC, Carrillo-Angeles I, Martínez-Peralta C, Golubov J. 2010. Reproductive biology of Cactaceae. In: Ramawat K. (ed.) Desert plants. Berlin/ Heidelberg, Springer. p. 197-230.

Marchi MNG. 2016. Aspectos fisiológicos, anatômicos e moleculares da propagação e conservação in vitro de espécies de cactos endêmicos da Bahia. PhD Thesis, Universidade Estadual de Feira de Santana, Feira de Santana.

Martínez-Peralta C, Mandujano MC. 2011. Reproductive ecology of the endangered living rock cactus, Ariocarpus fissuratus (Cactaceae). The Journal of the Torrey Botanical Society 138: 145-155.

McNeely JA. 2003. Biodiversity in arid regions: values and perceptions. Journal of Arid Environments 54: 61-70.

Meiado MV. 2012. Propagação sexual e assexual estruturando Populações de Tacinga palmadora (Britton \& rose) N. P. Taylor \& Stuppy, um cacto endêmico da caatinga. Revista de Biologia Neotropical 9: 6-13.

Meiado MV, Machado MC, Zappi DC, Taylor NP, Siqueira Filho JA. 2015. Ecological attributes, geographic distribution and endemism of cacti from the São Francisco watershed. Gaia Scientia 9: 40-53.

Molina-Freaner F, Clark-Tapia R. 2005. Clonal diversity and allelic relationships between two closely related species of columnar cacti from the Sonoran Desert: Stenocereus eruca and Stenocereus gummosus. International Journal of Plant Sciences 166: 257-264.

Nascimento JPB, Meiado MV. 2016. In situ or ex situ seed conservation: which is the more effective way to maintain seed longevity of an endangered cactus?. Plant Species Biology 32: 115-120.

Nei M. 1978. Estimation of average heterozigosity and genetic distance from a small number of individual. Genetics 89: 583-590.

Nobel PS. 2002. Cacti: biology and uses. Berkeley, University of California Press.

Oliveira JPL. 2013. Ecologia de Discocactus zehntneri subsp. boomianus (Cactaceae) em afloramento rochoso do semi-árido baiano (Brasil). MSc Thesis, Universidade Federal da Bahia, Salvador.

Ortega-Baes P, Gorostiague P. 2013. Extremely reduced sexual reproduction in the clonal cactus Echinopsis thelegona. Plant Systematics and Evolution 299: 785-791.

Palacios AM, Navarro RC, Ortega DBH, Avila VC. 2016. Micropropagation of Turbinicarpus valdezianus (Möeller) Glass \& Foster (Cactaceae) an Endemic Cactus in Northern Mexico. HortScience 51: 94-97.

Peakall R, Smouse PE. 2012. GenAlEx 6.5: genetic analysis in Excel. Population genetic software for teaching and research-an update. Bioinformatic 29: 2537- 2639.

Peñas ML, Oakley L, Moreno NC, Bernardello G. 2017. Taxonomic and cytogenetic studies in Opuntia ser. Armatae (Cactaceae). Botany 95: 101-120.

Pimienta-Barrios E, Castillo RF. 2002. Reproductive biology. Cacti: biology and uses. Berkeley, University of California Press.

Polis GA. 1991. Desert communities: an overview of patterns and process. In: Polis GA. (ed.) The ecology of desert communities. Tucson, The University of Arizona Press. p. 1-25.

Pritchard JK, Stephens M, Donnelly P. 2000. Inference of population structure using multilocus genotype data. Genetics 155: 945-959.

Qian W, Meng J, Li M, et al. 2006. Introgression of genomic components from Chinese Brassica rapa contributes to widening the genetic diversity in rapeseed (B. napus L.), with emphasis on the evolution of Chinese rapeseed. Theoretical and Applied Genetics 113: 49-54.
R Development Core Team. 2017. R. A language and environment for statistical computing. Version 3.4.1. Viena, R Foundation for Statistical Computing.

Rathcke BJ, Jules ES. 1993. Habitat fragmentation and plant-pollinator interactions. Current Science 65: 273-277.

Realini MF, Gottlieb AM, Font F, Picca PI, Poggio L, González GE. 2014. Cytogenetic characterization of southern South American species of Opuntia (Cactaceae-Opuntioideae). Succulent Plant Research 8: 31-50.

Rebman JP, Pinkava DJ. 2001. Opuntia cacti of North America - an overview. Flower Entomology 84: 474-483.

Ribeiro EM, Meiado MV, Leal IR. 2015. The role of clonal and sexual spread in cacti species dominance at the Brazilian Caatinga. Gaia Scientia 9: 27-33.

Santos MR. 2013. Filogenia molecular, taxonomia, biogeografia e conservação de Discocactus Pfeiff. (Cactaceae). MSc Thesis, Universidade Federal de Viçosa, Viçosa.

Santos MR, Machado MC, Garcia FC, Taylor NP. 2015. Taxonomic adjustments in Discocactus Pfeiff. (Cactaceae). Phytotaxa 207: 209-212.

Santos AP, Hassemer G, Meiado MV. 2018. Seed storage of B razilian cacti species in different threat categories. Plant Species Biology 33: 203-211

Scheinvar L. 1985. Cactáceas. Flora Ilustrada Catarinense. Itajaí, Herbário Barbosa Rodrigues.

Stearns SC. 1987. The evolution of sex and its consequences. Boston, Birkhäuser Verlag.

Stevens PF. 2001 onwards. Angiosperm Phylogeny Website. Version 14, July 2017 [and more or less continuously updated since]." will do. http://www.mobot.org/MOBOT/research/APweb/. 9 Mar. 2019.

Suehs CM, Affre L, Médail F. 2004. Invasion dynamics of two alien Carpobrotus (Aizoaceae) taxa on a Mediterranean island: I. Genetic diversity and introgression. Heredity 92: 31-40.

Torres-Silva G, Resende SV, Lima-Brito A, Bezerra HB, Santana JRF, Schnadelbach AS. 2018. In vitro shoot production, morphological alterations and genetic instability of Melocactus glaucescens (Cactaceae), an endangered species endemic to eastern Brazil. South African Journal of Botany 115: 100-107.

Ward JH. 1963. Hierarchical grouping to optimize an objective function. Journal of the American Statistical Association 58: 236-244.

Wilcock C, Neiland R. 2002. Pollination failure in plants: why it happens and when it matters. Trends in Ecology \& Evolution 7: 270-277.

Wolfe AD. 2005. ISSR techniques for evolutionary biology. Methods in Enzymology 395: 134-144.

Wolfe AD, Xian QY, Kephart SR. 1998. Assessing hybridization in natural populations of Penstemon (Scrophulariaceae) using hypervariable intersimple sequence repeat (ISSR) bands. Molecular Ecology 7: 1107-1125.

Zachar M. 2008. Nový taxón z brazilskeho štátu Bahia - Discocactus petrhalfari M. Zachar spec. nova. Kaklusy 44: 43-47.

Zappi D, Taylor N. 2018. Cactaceae in Flora do Brasil 2020 em construção. Jardim Botânico do Rio de Janeiro. http://floradobrasil.jbrj.gov.br/ reflora/floradobrasil/FB605271. 21 Dec. 2018.

Zietkiewicz E, Rafalski A, Labuda D. 1994. Genome Fingerprinting by simple sequence repeats (SSR) - anchored polymerase chain reaction amplification. Genomics 20: 176-183. 